\title{
The Role of Iran's «Soft Power» in Confronting Iranophobia
}

\author{
S.M. Mirmohammad Sadeghi, R. Hajimineh \\ Islamic Azad University, Tehran, Iran
}

«Soft power» is a set of activities designed by a government or regional and international actors aimed to influence external public opinion, promote external image or attract support for a particular policy, which is implemented through all the available tools and new technologies. The non-governmental actors also play an effective and important role in this diplomacy. Considering the public diplomacy and soft power of the Islamic Republic of Iran as a deliberate and conscious approach can be of great importance in the country's grand strategies that will strengthen national interests in the domestic sphere and influence them at regional and global levels. The article analyzes the role of Iran's soft power in confronting Iranophobia. The study is aimed at presenting a theoretical definition of public diplomacy and soft power in foreign policy and international system, and then examines its role in the foreign policy of the Islamic Republic of Iran with an emphasis on confronting Iranophobia.

The authors answer the research question: "What is the role of soft power in the foreign policy of the Islamic Republic of Iran in confronting Iranophobia?"

The research method is descriptive-analytical based on historical evidence, documents, and analytical issues of theorists, authors, and media being expressed in the theoretical framework of soft power. The paper is based on a synthesis of Stephen Walt's "balance of threat" theory with Alexander Wendt's social constructivism to explain the Iranian "threat" in American foreign policy.

The findings of this research show that without the use of force and disturbing the balance in the international relations, using a variety of tools and instruments the Iranian public diplomacy and soft power might be effective to reduce the global and regional atmosphere of Iranophobia and undermine anti-Iranian solidarity.

Key words: «soft power», public diplomacy, Islamic Republic of Iran, foreign policy, Iranophobia

\section{Introduction}

7 he «soft power» is understood as a new form of applying power in the international level that indicates the necessity of using more legitimate practices in order to achieve the foreign policy objectives with an emphasis on the intangible foundations of power.

УДК 327.8

Received: January 10, 2019

Accepted: August 15, 2019 
Effective governance by public opinion in the field of foreign affairs nowadays is jeopardized by various specified characteristics of modern democratic civilization (Speier 1950). Smart power is defined as the capacity of an actor to combine elements of hard and soft power in the way that they are mutually reinforcing each other, so that the actor's purposes are advanced effectively and efficiently (Wilson 2008).

Iranophobia refers to the policies based on conspiracy theory to achieve specific interests against the country by labeling Iran as a threat to a specific state, the regions of Persian Gulf, the Middle East, or to international peace and security. Iranophobia refers to hostility against the policy, culture, society, economy or the international role of Iran. In addition, Iranophobia means distrust, hatred, jealousy, discrimination, bias, racism, fear or disgust towards the Iranians as an ethnic, racial, lingual, and religious group accepted around the world.

Given the significant and strategic shifts in Iran's international stance after the victory of the Islamic Revolution, the country has been considered as a significant regional power by other regional and international powers. However, the discourse on its disagreements with the West begets conflicts with the western states, especially the USA.

Since its establishment by a revolution in 1979, the Islamic Republic of Iran has grappled with challenges. The post-revolutionary foreign policy of Iran was based on a number of cherished ideals and objectives embedded in the country's constitution, to wit: Iran's independence, territorial integrity, national security, sustainable national development. Beyond its borders Iran seeks to enhance its regional and global stature, promote its ideals, including Islamic democracy, expand the network of its bilateral and multilateral relations, particularly with neighboring Muslim-majority countries and nonaligned states, reduce tensions and manage disagreements with other states, foster peace and security at both the regional and the international levels through positive engagement, promote international peace through dialogue and cultural interaction (Zarif 2014).

In this regard, Iran also has its own soft power resources considering the civilizational, historical, religious and cultural background, and can be one of the successful countries in the application of cultural diplomacy in the region and the world in case of rational employment of these potential resources. Iranian soft power policy could be perceived as a pattern in the Islamic world due to messages and values that it emphasizes.

For the incumbent Iranian administration (from 2013 till now) confronting Iranophobia remains one of its main objectives that is being achieved by means of public diplomacy such as media, virtual networks, official public addresses, negotiations, non-governmental and public exchanges, adopting regional policy (constructive interaction doctrine) and balanced rationality.

The article discusses the role, the extent and the effectiveness of public diplomacy and soft power of Iran in confronting Iranophobia. The study also presents a theoretical definition of public diplomacy and soft power and defines Iranophobia. Independent variable of the study is the public diplomacy of foreign policy of the Islamic Republic of Iran, depending variable is confrontation against Iranophobia. The research method is descriptive-analytical based on historical evidence, official documents, relevant research and theories, media sources. 


\section{Theoretical framework}

Public diplomacy is a relatively new concept used in international relations during the last fifty years. This term was coined by Edmund Gullion, the head of Fletcher School of Law \& Diplomacy at Tufts University in 1965 (Snow, Taylor 2009: 18). Although it has carious connotations in the theories of international relations, in general it means the efforts made by governments, international organizations or other actors of world politics (including non-governmental organizations) to enforce mutual understanding affecting the foreign audience. The triangle of a politician, media, and a citizen is of great significance in soft power and public diplomacy.

Joseph Nye, one of the most prominent researchers in international relations, introduced the term "soft power" as the ability of promoting interests and priorities by using valuable but intangible assets such as attractiveness, culture, political values and institutions, as well as legitimate and moral policies. Nye's book entitled "The Paradox of America Power" presents two faces of the USA including hard power (military and security) and soft power (persuasion and attraction) (Nye 2002). Soft power of a country, therefore, depends on three sources: the culture of that country (when the culture is attractive to others), the beliefs, ideals and political values of that country (when the values are perceived positively inside and outside) and the foreign policy of that country (when these policies are considered legitimate and have moral credit). These components of soft power can manifest themselves inside the country (e.g. the democracy, or religious democracy in Iran), in international organizations (working with others or replication of power), and in foreign policy (justice, human rights, and peacemaking policy) and seriously affect the priorities of others. The media, Internet, social networks are significant tools of soft power and public diplomacy. Countries use media to advance their policies; media presents correct or incorrect information in the interests of states and actors and cause different pressures on the rivals by inspiring public opinion against a country or an issue.

Nye also describes the possible combination of soft and hard powers and calls it "smart power". The mere use of soft or hard power is likely to be ineffective, while smart combination of the both powers should be efficiently employed to achieve the desired goals. Nye defines the military and economic power ("carrot and stick" policy against governments and nations) as hard power but the cultural-value and legitimate foreign policy (creating attractiveness and achieving the hearts and minds of governments and nations) as soft power and elements of public diplomacy. In fact, he considers the smart balance between soft power and hard power according to the regional and international context as the smart power and believes that the secret of leaders' success is in mixing soft power and hard power in different contexts (see Table 1).

Analyzing the political, social, and cultural dimensions of public diplomacy, it is important to pay special attention to the social constructivist approach, according to which individual state interests and strategies are based on the historical, political and cultural contexts within which the state operates. 
Table 1. Dimensions of Power according to Joseph Nye

\begin{tabular}{|c|c|c|}
\hline Behavior type & Resources & Type of power \\
\hline Economic force, threat or encouragement & Military and economic force & Hard power \\
\hline Persuasion and attraction & Culture, education and communication technology & Soft power \\
\hline
\end{tabular}

Source: (Asghari 2011:16)

Andrei Tsygankov argues that both internal and situational factors of national identity - which ultimately shape the national interests - are significant. He stresses that local conditions such as "the state of the economy, relations among different social groups, or the type of the political regime" (Tsygankov 2016) should not be ignored, since they are just as important in shaping national perceptions as the "significant Other" who establishes the meaningful context for the actor's existence and development.

\section{New public diplomacy}

Traditional public diplomacy uses international TV channels, promotes exchange of students, researchers, scholars, and artists, holds festivals and exhibitions, establishes cultural centers, provides language teaching and creates business associations which are still ubiquitous. However, new public diplomacy includes the relations of a society in a country with the societies of other countries to affect the governments of those societies. The distinction between the two types of public diplomacy became apparent in the early years of the XXI century. Some changes in the methods of diplomacy have been observed in recent years in the light of fundamental evolutions occurred in world politics. Deep evolutions in the field of information technologies and communications, wide access to the Internet, globalization and citizen diplomacy have changed the concept of power. Nowadays, not only the economic or military power (hard power), but the reputation of a nation or a leader, the country's values, policies, performance and the ability to control the information influence an image of a country in international relations. Thus, new public diplomacy is applied not only by states but also by non-governmental institutions and individuals, in relations between societies of two or more countries. Such diplomacy relies on soft power and creates mutually strengthening relations (Table 2) (Melissen 2011:2).

Diplomacy now exists in three forms: traditional diplomacy, public diplomacy and new public diplomacy. While traditional diplomacy, that has existed for centuries, includes the relations between governments. Public diplomacy implies the ties between a government and society of another country and affects the governments of this society (Nargesi 2014). Image cultivation and propaganda now labeled as public diplomacy are as old as diplomacy itself (Melissen 2005). The Diagram 1 shows the definition and relationships between three forms of diplomacy. From this perspective, public diplomacy has the best efficiency when all up-arrows are coordinated (Leonard, Stead, Smewing 2002). 
Table 2. The comparative diagram of traditional diplomacy, public diplomacy, and new public diplomacy

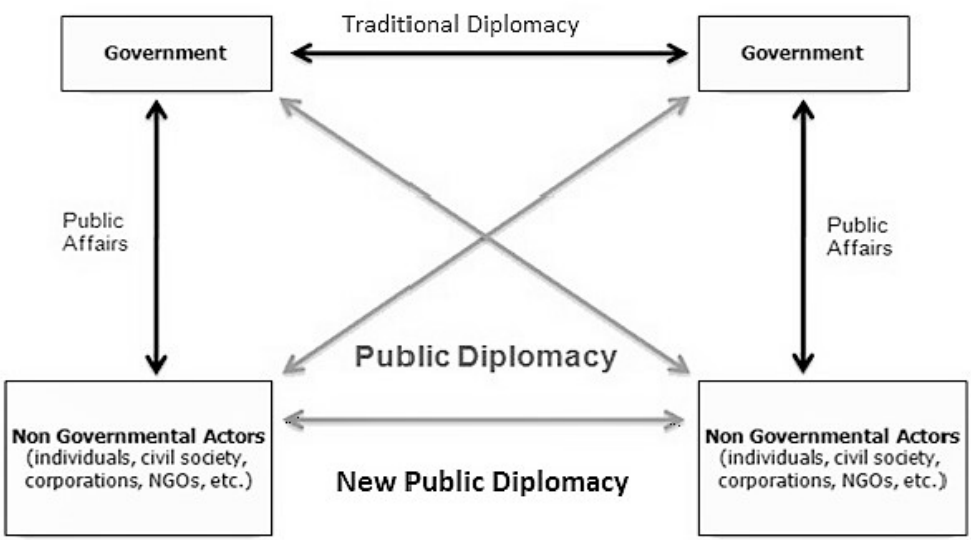

Source: (Gurgu 2016: 128)

\section{Diagram 1. Diplomacy typology}

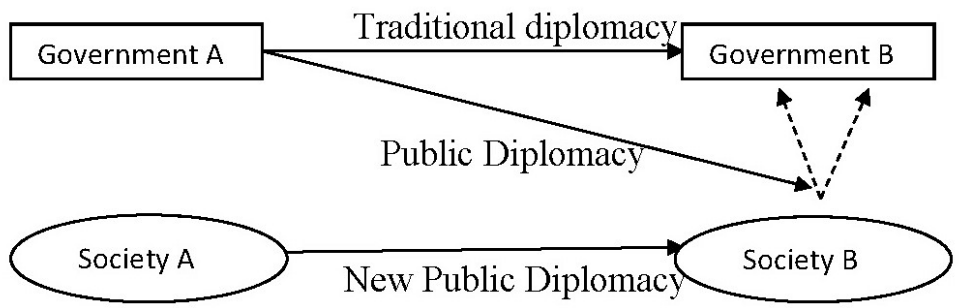

Source: $h t t p: / / w w w . i i r j o u r n a l . i r$

\section{Tools of Iranian public diplomacy and soft power}

Iran's soft power and public diplomacy have three pillars. The first and foremost is history and culture of a seven thousand year civilization that had an impact on neighboring regions. In the same context, tourism and cultural events are other important sources. The Farsi language can be seen as a major source of attraction since it has synthesized with many other languages including Turkish, Hindi, Urdu, Armenian, Georgian, Swahili and others. Five million Iranians in diasporas also play a significant role in spreading Iranian culture through Iranian restaurants, goods, songs and other aspects. The second pillar is political values. Iran introduced a unique political model that stems from Iran's hybrid political system which adopts the concept of a "religious democracy". As a unique model and source of Iranian soft power, this model constitutes a substitute for traditional systems and is considered as an appealing model for religious Muslims. The third pillar of Iran's soft power is its foreign policy. Iranian Constitution refers to the role of foreign policy based on Islamic values, fraternal commitment to all Muslims, and full protection of the oppressed around the world. These principles are considered the foundation of Iran's soft power (Tamdemir 2017: 4). 


\section{Language, religion and ethnicity}

Iranians have ancient and glorious state tradition, and they are proud of it since it is a foundation of their identity. For example, one of the sculptures of from Persepolis, the capital of ancient Iran, was chosen as the symbol of Iranian airlines. In addition, many avenues use ancient cultural symbols to design goods from jewelery to clothing.

Given Iran's historical role in the 'Greater Iran' region (encompassing the Caucasus, West Asia, Central Asia, and parts of South Asia), the country has the potential to exert soft power to a 'natural market' (as it was in the past) and advance its national interests. Therefore, the country can acquire greater influence regionally if, in addition to religious bonds, it skillfully invokes common historical, cultural, ethnic and linguistic ties with neighboring states.

Iran has been targeting Shiites in many countries around the world, through media campaigns, establishing cultural and religious centers, financially supporting Shiite minorities and recently politically and militarily assisting Shiite and Sunny communities in order to strengthen their role and influence in Lebanon, Iraq, Afghanistan, Syria and Yemen.

Since the founding of the Islamic Republic in 1979, Iran has relied on its unique Shiite character as the basis of its soft power to galvanize support from pockets of Shiite populations in a Sunni-dominated Middle East and Central Asia. This policy has been deliberate and strategic, with clear ideological underpinnings. While it has been successful - including Iran's manifest clout in Lebanon and Syria, or in Iraq after Saddam Hussein - its net effect is, by definition, limited in scope and geography, constraining Tehran's ability to generate long-term strategic dividends.

Indeed, relying on the Shiite character in soft power projection is arguably inconsistent with the Constitution of the Islamic Republic, which requires the government to formulate its foreign policy on the basis of "fraternal commitment to all Muslims," and its general policies "with the view to cultivating the friendship and unity of all Muslim peoples." Moreover, just as it limits the full reach of Iran's soft power beyond the Shiite world, this approach also contributes to sectarian divisions in the region, entrenching alliances further along sectarian lines. This is self-defeating, as it not only complicates Iran's enough already difficult security environment, but also further isolates the country from its geopolitical space. To be clear, the argument is not to abandon Iran's Shiite brethren, but to adopt policies and postures which could strengthen Iran's ability to more effectively project positive influence and advance the country's interests beyond the confines of the 'Shiite world', and to stabilize its immediate neighborhood. Iran tries to develop the image of a "defender state" for these social groups. Iran ought to defend Shiites and ethnic Iranians. Iran has developed close ties with religious movements that have embraced Shiism and have been active at certain levels in many Islamic countries (Tamdemir 2017). The US invasion of Afghanistan and then Iraq by the US after 9/11 resulted in increasing Iran's influence in these two countries. Then Iran, which realized that the political-social revolutions that started with the Arab Spring were moving towards it with the domino effect, adopted a stopping strategy in Syria and reassigned itself a new role. 
In order to understand the rise of Iran as a regional power, it is necessary to examine the mechanism of acquiring allies and influencing others. The core of the Iranian strategy is the "revolutionary ideology", which is also called "Islamic resistance", in which a war for existence against the imperialist forces and extremist dynasties continues. By implementing foreign policy based on religious discourses, it is possible to stress that Iran applies a strategy to win more peoples in the Middle East than prowestern regimes.

In the first postrevolutionary years "revolution export" was declared as Iran's official policy. There are two basic approaches to the issue of revolution exports in Iran. The first is an idea of exporting a cultural revolution that aims at revolutions in other countries, and the second is the idea of the cultural revolution, which is called the main continental theory, emphasizing the values of the revolution instead of physical revolution export. The effective use of soft power elements also makes sense at this point. What is meant by the export of the cultural revolution is the dissemination of revolutionary goals, ideals, teachings and discourses to the peoples of the world. They have begun to emphasize that the most prominent feature of the Islamic Revolution is its cultural dimension. So now the main component of Iranian soft power is its culture. This cultural axis can be mentioned as a cultural revolution in itself or as general diplomacy. The intention of exporting cultural revolution is to influence others by soft power without benefiting from physical violence and power. The aim is to influence others' thoughts and behavior and direct them to behaviors similar to those in the country where the revolution is taking place (Tamdemir 2017: 14).

\section{Cultural, media and communication channels}

The Iranian cultural diplomacy activities were undertaken by the Islamic Culture and Relations Organization (ICRO). The ICRO is affiliated to the Ministry of Culture and Islamic Guidance. Its functions include the following: to establish cultural relations among various people of the world in order to develop dialogue and common language arrangements, promote cultural exchange, explain Iranian-Islamic culture and civilization, develop cultural relations with other states and international organizations, work for the Islamic welfare developing the dialogue between religions and civilizations. The institution has the Iranian Cultural Representatives all over the world. The purpose of the ICRO is "promotion of cultural ties with other nations and communities; consolidation of cultural ties of the Islamic Republic of Iran with other nations; proper presentation of the Iranian culture and civilization; preparing the grounds for unity among Muslims; revival and promotion of Islamic culture and teachings in the world; information dissemination about the principles and realities of the Islamic Revolution". The Islamic Culture and Relations Organization is Iran's de facto public diplomacy organization.

The organization has opened offices around the world, even though it has anticipated its goal of establishing close relations with Muslim peoples. In addition to

\footnotetext{
1 Official Website of the Ministry of Culture and Islamic Guidance of Iran. URL: https://www.farhang.gov.ir/en/home (accessed 12.07.2019)
} 
spreading the Farsi language and culture in these offices, close relations with the Shiite communities in the countries are also being developed. Nonetheless, the Cultural and Islamic Relations Agency gives priority to Muslim countries, e.g. in Iraq, Pakistan and Lebanon.

Iran publishes six newspapers in English and Arabic for citizens of other countries. Iran News, Iranian Daily, Tehran Times, Keyhan International are published in Europe, North America, Asia and Africa. Al-Vefagh and Keyhan Arabic target Arab speakers in the Middle East and Africa (Nargesi 2014: 15). In addition, Iranian Radio and Television Corporation has ten television channels broadcasting abroad. These channels are Jam-i Jam 1, 2, 3; Al-Alem; Sahar TV 1, 2, 3; Al-Kowsar; Press TV; and Hispan TV. Moreover, Iran broadcasts programs in 20 languages, namely Arabic, Turkish, Urdu, Pashtuca, Hebrew, Kurdish, English, Japanese, Hindi, Bengali, Chinese, Indonesian, Armenian, Russian, Georgian, Bosnian, Italian, German, French, Spanish.

Friendship associations

The number of existing friendship and cooperation organizations between Iran and other countries is forty five. 5 of them are in the Middle East, 10 - in Asia-Pacific, 7 - in Central Eurasia, 12 - in Europe, 5 - in Africa, 2 - in North America and 4 in Latin America. Likewise, Iran organizes Iranian Culture Week events in about 30 states (Tsygankov 2016: 14).

\section{Universities}

Iranian Ministry of Science, Research and Technology has opened university branches in Venezuela, Lebanon, UAE, Pakistan, Armenia and Tanzania. It has also made plans in Afghanistan, Tajikistan, Canada and Malaysia. It was decided to establish the Iran-Afghanistan University in order to realize joint research and engineering projects. Iran has established the branch of Azad University in Afghanistan as well as Hajj Abdullah Ensari University in Herat as the branch of the Iranian University of Science and Technology.

According to the official data, in 2018 some 55,000 foreign students are studying in Iran. 27000 foreign students study in Governmental universities, 17000 - as religious sciences students in Al-Mostafa International University, 10000 - in Islamic Azad university, 2500 - in universities of health sciences.

\section{Iranian and Farsi Language Institutions}

The Iranian state has established over 600 Iranian centers in 45 countries. There are 13 centers in 5 Middle East countries, 38 centers in 8 Asia-Pacific countries, 203 centers in 7 Central Eurasia countries, 281 centers in 21 European countries, 1 center in Ghana and 99 centers in North America. In the same way, there are around 100 Farsi language learning centers in different countries of the World.

\section{Tourism}

One of the oldest civilisations in the world, Iran is home to 19 UNESCO World Heritage sites with rich legacy of art, culture and architecture dating back three millennia. As for tourism, international travelers rave about Iran's natural beauty, as well as its ancient ruins, mosques and first-class museums. There are about 70 thousand 
tombs (most of them belong to Shiite Imams and their families) and sacred places in Iran, with the most famous being Naghsh-e-Jahan Sure, one of the largest city squares in the world. The square is surrounded by important historical buildings from the Safavid era. The square was at the heart of the Safavid capital's culture, economy, religion, social power, government, and politics. Its vast sandy esplanade was used for celebrations, promenades, and public executions, for playing polo and assembling troops ${ }^{2}$. As one of the first sites in Iran to be registered with UNESCO in 1979, this square was built by Shah Abbas in the $17^{\text {th }}$ century ${ }^{3}$.

Persepolis is another famous place. Founded by Darius I in 518 B.C. it was the capital of the Achaemenid Empire. built on an immense half-artificial, half-natural terrace. The importance and quality of the monumental ruins make it a unique archaeological site. In 1979 the ruins were designated a UNESCO World Heritage site.

Shushtar Historical Hydraulic System is registered in 2009 and hailed as a "masterpiece of creative genius" by UNESCO. This ancient irrigation system dates back to Darius the Great in the $5^{\text {th }}$ century B.C. Shushtar is unique hydraulic technique developed during ancient times to aid the occupation of semi-desert lands. It involved the creation of two main diversion canals on the river Karun one of which, Gargar canal, is still in use providing water to the city of Shushtar via a series of tunnels that supply water to mills.

\section{Cinema}

There is no doubt that Iranian feature films are successful. Today, Iranian cinema is recognized as one of the most innovative and exciting in the world and films from Iranian directors are screened to increasing acclaim at international festivals. The key to resolve the apparent contradiction between Iran's repressive image and the renaissance of Iranian cinema is to understand the relationship that developed between art, society and the state after the Islamic revolution (Mir Hosseini 2001). In its early years Iranian Fajr Film Festival (which has taken place since 1983) had a competition section for professional as well as amateur films. From its very onset it was intended to be as magnificent and spectacular as possible. It had a background as powerful as that of the Tehran International Film Festival and wanted to remain on the same track. Since 1990, there has been an international along with the national competition. The festival also features a competition for advertisement items like posters, stills and trailers. In 2005 the festival added competitions for Asian as well as spiritual films. The top prize is called Crystal Simorgh ${ }^{4}$. Although the Fajr Film Festival is not yet ranked among the top film festivals, it has been successful in making policies and setting patterns for the future of Iranian cinema ${ }^{5}$.

\footnotetext{
2 UNESCO Official Website. URL: http://whc.unesco.org/en/list/115 (accessed 12.07.2019)

3 Culture Trip. URL: https://theculturetrip.com/middle-east/iran/articles/top-10-unesco-world-heritage-sites-in-iran (accessed 12.07.2019)

4 Islamic Republic News Agency. URL: https://en.irna.ir/news/82828808/Fajr-Film-Festival-announces-winners (accessed 12.07.2019)

${ }_{5}$ Mehrabi M. F for Festival. Massoud Mehrabi. URL: http://www.massoudmehrabi.com/articles.asp=1137857131 (accessed: 01.03.2019)
} 


\section{The objective examples of Iran soft power and public diplomacy}

Edward Wastnidge (Wastnidge 2015) believes that Iran's public diplomacy is used to promote its soft power and improve its image on the world stage. Iran is both a theocratic and a republican state, so given this duality of Iranian leadership, Wastnidge takes a two-part approach to Iran's use of public diplomacy. Firstly, he assesses the country's presidential-led cultural initiatives to promote Iran's public image overseas, including President Hassan Rouhani's social media-based "Meet Iran" campaign. Secondly, he analyzes the Supreme Leader's use of international broadcasting to maintain a "soft war" between Iran and the West. Wastnidge concludes that since Iranian soft power is enacted through a range of different actors and channels, its use on the global stage can produce «differing strategic, and at times defensive, narratives» (Wastnidge 2015: 364).

Wastnidge mentioned that Iran's public diplomacy and the "soft war" attempts to extend its soft power reach through the following means.

The ICRO, as it was mentioned above, is responsible for coordinating Iran's bilateral cultural initiatives with other states and in some ways it can be seen as a similar enterprise to the British Council, or Confucius and Goethe Institutes. It carries out its activities under the guidance of the Supreme Leader who directly appoints members of the ICRO's council. Its primary aim is to promote the ideals of the Revolution, encourage Islamic unity and strengthen relations with Muslim countries. Its importance in terms of Iran's soft power is that it appoints the senior cultural representatives (known as cultural councilors) serving abroad.

These representatives work independently but sometimes in cooperation with Iran's embassies, and head up Iran's cultural centers abroad. The main initiatives it undertakes in terms of delivering Iranian soft power will often depend on the country in question, but primarily involve organizing Iranian cultural weeks/exhibitions, arranging cultural and religious events for Iranians living abroad, building links with cultural institutions in the host country and promoting Farsi language learning. The ICRO also runs the Al-Hoda international publishing house, which produces literature on the Islamic Republic and Iranian culture in 25 languages and supplies much of the resource for the libraries that are open to the public at the ICRO cultural centers.

The ICRO has offices around the world including several European capitals, but they are especially active in neighboring countries, with Pakistan and Turkey hosting eight and two ICRO centers accordingly. One of the most active ICRO offices is operating in Tajikistan, where the organization has provided funding for the promotion of Farsi language and literature resources and coordination for a number of conferences and cultural events related to shared cultural figures such as the great Iranian poet Rudaki. While the focus is on fellow Muslim states, the ICRO establishes cultural centers across the non-Muslim world; it should be noted that Iranian cultural diplomacy through the ICRO reflects local characteristics. Thus, this strategy emphasizes figures relevant to the Persianate world in the ICRO's activities in Afghanistan and Tajikistan, 
on the one hand, and religious ties among fellow Shiite communities in Lebanon and Pakistan, on the other.

Iran's international media output is the second conduit through which it attempts to extend its soft power. The international broadcast media is under the control of the state broadcaster Islamic Republic of Iran Broadcasting (IRIB). The World Service arm of IRIB seeks to promote Iranian culture and civilization to international audience, expounding the Islamic Republic's worldview in the light of perceived biases in the international news media in particular.

There is also a strong defensive element within this thinking as the Islamic Republic has long been subject to broadcasts from Western media organizations which it sees as being hostile, such as Voice of America, numerous private stations run by the Iranian diaspora and, more recently, BBC Persia. IRIB currently runs five international news channels. Iran's first 24-hour foreign language international news channel, the Arabic-language "Al-Alam", began broadcasting in 2003. It is aimed primarily at Iraq, but also covers news on Lebanon, Palestine, Africa and Iran. Iran's second Arabiclanguage service, "Al-Kowthar", was launched in 2006 and focuses more on religious programming reaching out to fellow Shiite communities in the Arab world. IRIB also provides programming for the Hezbollah media outlet "Al-Mandar" in Lebanon, thus furthering Iran's media reach - albeit indirectly.

Perhaps the most well-known Iranian media enterprise in the West is its 24-hour English language international news channel "Press TV", launched in 2007. It claims to offer a different perspective to CNN, BBC World, Al-Jazeera English and others. In 2011 Iran also launched "Hispan TV", a Spanish-language station broadcasting to Spain and Latin America, which reflects the ties cultivated between Iran and the Latin American states, most notably Venezuela and Cuba, during the Ahmadinejad era. As with "Press TV", however, "Hispan TV" was also removed from the main satellites in 2013 as a result of the tightening sanctions against Iran.

In the same vein, Iran's multi-ethnic, linguistic and religious diversity should also be seen as an important part of the country's soft-power toolbox. Iran should fully embrace this diversity not just for its intrinsic virtues, but also to ensure internal stability, and to demonstrate to the world that the country has an open and tolerant society. With a number of militant organizations, conceived on ethnic lines (and often supported by external elements) operating in Iran and posing a threat to national security and unity, Tehran's countermeasures should include a targeted strategy of winning the hearts and minds of the country's ethnic minorities in order to strengthen their loyalty to the country. With ISIS and other external threats increasingly looking to infiltrate and recruit within Iran, the proposed policy is much more pressing (Ersig, Toyserkani 2009).

It is conceded that Iran does not benefit from the safety buffer of geographical isolation. As such, concessions with respect to the country's minorities can have a geopolitical dimension. Where it is legitimate, the government should properly address the grievances of these minorities. Intense and active consultation with minority groups much more than seen to date - should form part of the state strategy. The socioeco- 
nomic health of ethnic minorities in the aftermath of sanctions lifting obviously needs attention of Tehran. Demining internal discord in the country can only help Iran to gain more sustainable influence beyond its borders, and to parry disruptive forces and designs from outside the country. While there is no substitute for Iran's military capabilities, which clearly has its place in the country's national security strategy, the soft power dimension is for now underplayed and underappreciated in Tehran. The Middle East is in dire need of easing tensions and reversing the perpetual security dilemma which condemns it to recurring conflicts. Iran is well placed to play that constructive leadership role, and it has every interest to do so. A proper national soft power strategy might be "the energy" that the country and the region need to reckon with some of the vexing challenges of this century.

\section{Iranophobia}

The Iranophobia Project is considered in Iran to be a strategy of the United States of America that seeks to undermine the development and authority of the Iran by threatening to undermine the regime by creating a panic and changing the behavior of international actors. "The project", a split from the soft war against Iran, is aimed at weakening and isolating Iran. It should be noted, however, that Iran is not a new subject of phobia, and this has been repeatedly done by Western countries against Iran. In fact, repeating the aforementioned subject from the Western bloc is a soft threat strategy that has taken a wide range of media and diplomacy over time and is in the process of forming a large-scale psychological operation against the Islamic Republic of Iran. The extension of Iranophobia can vary from personal hatred to institutionalized pursuit and harassment. Furthermore, sometimes Iranophobia overlaps the anti-Iranian feelings (Nargesi 2014: 13).

Israeli lobby groups are one of the main sources of intensifying and expanding Iranophobia in the US, Europe, and some target countries which have always attempted to confuse the public opinion and thoughts of elites, politicians, and western decision makers with Iran and destroying the image of this country.

Haggai Ram, the board member of Ben-Gurion University in the first chapter of his book (Ram 2009) presented three reasons for the hostility of the Islamic Republic of Iran and Israel as follows: 1) religious oriental and Islamic reactionary dictatorship in conflict with western democracy and secular Jewish ally;2) strategic competition on power and dominance in the Middle East; 3 ) the strategic concern on Iran demand to destroy Israel (Ram 2009: 31-60).

The author summarized the most significant reasons of hostility in a term "mental turmoil." He compared the processes in Iran and Israel and described an atmosphere leading to the conflict of tradition and modernity, and this is the base for the common conception in Israel (Ram 2009: 31-60).

Phobia literally means fear, dread or horror and this meaning is exactly the same scenario that is followed by the USA and its regional allies by creating "Iranophobia 
project" as well as being sensitive to the authority and capabilities of the Islamic Republic of Iran. This approach is the product of a common policy between the USA and Israel and some Arabic countries.

Thus, Iranophobia is a strategic project aimed at introducing Iran as a big threat in the region and to the global peace and security in order to weaken the regime. In this regard, the domination system has put the isolation of Iran on its agenda to marginalize and isolate the Islamic Republic of Iran from relations with its neighbors and other countries in the world and minimize the influence of Iran because the West cannot tolerate the developed and powerful Iran and accepting Iran as a regional power means the failure and frustration of the West (Malek Mohammadi, Davoodi 2012).

\section{Understanding Iranophobia}

Understanding Iranophobia in American foreign policy requires understanding certain theoretical aspects of International Relations. Iran's tangible military capacity is not up to par with several regional actors in the Middle East and certainly nowhere close to the capacity of the US (Ersig, Toyserkani 2009). Despite this, Iran is seen as a major threat and destabilizing actor in the region. This paper is based on a synthesis of Stephen Walt's "balance of threat" theory with Alexander Wendt's social constructivism to explain the Iranian "threat" in American foreign policy. Walt's theory is based on the balance of power model which posits that states come together to balance and prevent the rise of a hegemony and maintain equilibrium. However, this theory has always been subject to criticism. Many analysts have pointed to how states failed to balance American hegemony after the fall of the Soviet Union or how states have often allied against relatively weaker powers, e.g. as Britain and France allying against Germany in the 1930's (Guha 2009: 5). Walt (Walt 1985) explains this inconsistency by asserting that states do not balance on the pretext of power differences but on their assessment of threats. Japan and China did not bandwagon to balance the US - a stronger power - in the 1990's because expected no threat from it. Britain, France and the US did ally against Germany, a relatively weaker power during the Second World War, due to their assessment that Germany posed a threat. Walt's argument holds true in many other cases. In South Asia Nepal, Sri Lanka and Bangladesh did not choose to ally with Pakistan to balance dominant India owing to a lack of perceived threat. However, in the Middle East divergent actors like Saudi Arabia and Israel have allied with the US to balance a perceived Iranian threat.

However, the question remains, how serious is the Iranian "threat" to the US and its allies in the region? Walt (Walt 1985: 9) asserts that four factors govern a state's assessment of threat and, therefore, its decision to ally or oppose: aggregate power, proximity, offensive capability and offensive intent. Walt (Walt 1985: 9) defines aggregate power as "a state's total resources" (i.e., population, industrial and military capability, technological progress). While Iran is a powerful state and has accumulated a degree of wealth from oil revenue, its aggregate power is by no means disproportionately 
higher than other major actors in the Middle East and certainly not the US. In terms of offensive capability, in 2017 Iran spent 3.1\% of its GDP on the military, compared to the $10.3 \%$ of Kingdom of Saudi Arabia (KSA) which is the third-largest military spender in the world. In military expenditure, Iran lags behind countries like KSA, Turkey, Israel, Jordan, Oman and Kuwait (Guha 2019: 5).

Furthermore, Iran maintains a primitive air force acquired from the US before the 1979 revolution. In terms of offensive intent, Iran has been accused of being a threat to its neighbors. While the aggressive rhetoric from Ahmadinejad has not destroyed this perception, it is fallacious to assume that Iran offers more offensive intent than KSA which makes no secret of its hostility towards neighbors like Yemen, Bahrain, Qatar and Syria.

Among Walt's criteria, proximity can be the only actual reason to consider Iran as a threat. Iran's geographical position gives it lucrative access to the Strait of Hormuz, through which a third of all the oil trade from the Middle East passes to major energy consuming states like India, Japan and China. Further, Iran not only has access to Iraq and the Arab monarchies of the Gulf, but also is a gateway into Central Asia. However, Iran's geographical proximity to Afghanistan has been used by the Americans in 2001 to act against Al Qaeda. This brings up the question of why Iran wasn't considered a threat then, but merely a year later, placed on an "axis of evil"? (Guha 2019: 6).

Thus, when placing Iran within Walt's model, it is very difficult to view Iran as the sort of threat conceptualized by Donald Trump. This is where constructivism may be insightful. As one of the leading scholars of social constructivism, Alexander Wendt (Wendt 1992) highlighted the role of a state's identity as an indicator of how other states would react to them in terms of security considerations. In Wendt's article (Wendt 1992), the manner of interactions between states go a long way in their assessment of threat and security. By this logic, Ayatollah Khomeini's anti-Western, "revolutionary" rhetoric would be a natural enticement of threat perception from Iran in American eyes. However, Iran has witnessed a full spectrum of leaders after Khomeini, from right-wingers like Ahmadinejad, to reformists like Khatami as well as centrists like Rafsanjani and Rouhani. Why then has Iranophobia remained constant? (Guha 2019: 8).

It is not inconceivable then, that Iran today is a "threat" because it is constructed as one. To clarify, this doesn't imply that Iran is an innocent player in the region. However, the notion of the Iranian threat being a construct holds true to the extent that Iran is not a fantastical malicious power with infinite resources and covert forces spread across the Middle East, ready to engage in dubious and conspiratorial activities against America and its allies. While this may seem exaggerated, it is precisely the picture Trump created in his speech to the United Nations in 2018, claiming that Iran is a major evil that creates "chaos, death, and destruction... and spread mayhem across the Middle East and far beyond" (Guha 2019: 8). But it is clear that, nowhere was the US image more negatively viewed than among publics in Muslim-majority countries (Zaharna 2009: 1). 
It is inconceivable that the US and Israel, two states that possess the most sophisticated intelligence and espionage networks in the world, could be unaware of Iran's capacities. Since the removal of Ahmadinejad from office, anti-Western rhetoric has been replaced by demands for multilateral cooperation under Rouhani. If Wendt's model is true, the reconciliatory signal from Iran should have sparked a cautious but marked détente from the US. However, instead, Iranophobia has skyrocketed since Trump assumed office.

What do the proponents of Iranophobia stand to gain from this? It posits that the US requires a fantastical evil to justify its actions in the Middle East, without which its actions would be seen as provocative and contrary to US's identity as the propagator of democracy and freedom. In the past, this "great evil" was the Soviet Union and the threat of Communism. Today, Iran as the "great evil" that should be subject to containment is an idea sold to the American people (and the global community) to justify America's interests in the region. These interests range from Israeli influence, geopolitical concerns, political and economic profiteering. This implies that regardless of capabilities or intent, assuming a lack of radical change in the Iranian or American elite, Iran is likely to remain a "great evil" in American foreign policy for the near future. This prospect is explored in greater detail subsequently (Ersig, Toyserkani 2009: 10).

\section{The soft power of Iran to confront with Iranophobia}

It can be stated that the soft power of the Islamic Republic of Iran to cope with Iranophobia in the USA and broader - the West, based on Joseph Nye's model, has several dimensions. Based on Joseph Nye, soft power has three important dimensions each one being related to each other and derived from three fundamental components, daily relationships with people and message transfer, the establishment of thematic strategic relations, and the expansion of long term relations with key people in target countries. These three components in the present era explain the main axes of new public diplomacy in powerful countries in the field of international relations. The Islamic Republic of Iran has used three components to cope with Iranophobia.

\section{Communications and message transfer}

Resorting to soft power message management can be defined as the main and central core of this power. In fact, message management refers to a process where the desired message of public diplomacy is processed based on the audience, subject, and time period and then transferred to the audience. Message can be designed for a short term process such as the media reaction to an important event and also get prepared for a long-term horizon for the audience (Nargesi 2014: 12). The source of this message should consider the characteristics and conditions of the audience. Using the media tools is one of the most effective ways to communicate with the audience. The media are the mediators among citizens and politicians. It can be stated that the structure of policies in the present era are formed by the media. In fact, power is scattered, splinted, and complicated in the present era but it can be said that power is based on the waves 
of media and whoever governs the media can play in the media. On the other hand, the elements such as trust making and the updated requirements of the society and the world should be considered.

In order to communicate directly with the foreign audience and transfer the message, president Rouhani wrote a note for the Washington Post entitled «The Time for Constructive Interaction Has Arrived $»^{6}$ on September 20, 2013 to announce the doctrine of constructive interaction as one of the principles of Iran foreign policy aimed at breaking the atmosphere of Iranophobia. Then he declared the principles of state's foreign policy in an interview with NBC News while travelling to New York for the United Nations General Assembly. Later this year returning from New York he re-announced the foundations of foreign policy in an interview with PBS. In addition, during five years of governance by the current government, president Rouhani has attempted to transfer his message to the audience through his interviews with foreign channels especially the American ones, which are the origin of producing Iranophobia.

Furthermore, the foreign minister of Iran has directly communicated with foreign audience to transfer the message through submitting multiple articles in popular media such as the Washington Post, New York Times, Der Spiegel, Le Monde, Times, $\mathrm{Al}$-Safir, and Al-Sharq Al-Awsat as well as in different interviews with famous foreign and domestic channels.

The active presence in the media, Internet and social networks, and direct communication with foreign audience especially by the foreign minister of Iran became the other significant and effective tools for message transfer and communication. The minister of foreign affairs has declared the positions of Iran via his personal Tweeter, Facebook, YouTube, Instagram and other social networks. This way of communication has had large significance and effect among the users.

The establishment of thematic-strategic communication

After determining the process of message management, the mechanism of soft power should establish the strategic communication with the foreign audience to follow its goals. In other words, it stabilizes the desired message content in audience mind and completes the process of message transfer by creating an executive, propaganda, cultural and media agenda. The strategic communications look at specific applications of both the mass communication and network communication approaches. The USA has applied these approaches drawing on examples from the US's post-9/11 public diplomacy in the Arab world (Zaharna 2007: 222). For this purpose, the executive structure of soft power creates a content for the foreign audience and produces a series of strategic messages with different forms and content by using a series of activities related to public diplomacy. Moreover, it stabilizes the core message in the mind of the audience through exaggeration and repetition in the medium term.

\footnotetext{
6 President of Iran Hassan Rouhani: Time to Engage. Washington Post. URL: https://www.washingtonpost.com/opinions/president-of-iran-hassan-rouhani-time-to-engage/2013/09/19/4d2da564-213e-11e3-966c-9c4293c47ebe_story. html?noredirect=on (accessed: 01.04.2019)
} 
In relation to creating strategic relations, the main approach is the mutual coordination and cooperation among different groups that will create a context for the mutual trust and counteraction among the audience and activists of soft power. Such relations are made in form of certain arrangements such as student exchange or training courses. Creating a close ties with the audience has a higher effectiveness than using mass media to affect the public opinion. According to the experts on soft power, creating the strategic relations between public diplomacy and local media of the target country to transfer the message to the audience fosters effectiveness with higher reliability than the direct use of foreign media among the audience of the target country. Another advantage of creating strategic relations in the durability of these relations than the other methods of message transfer to foreign audience and this fact has highly considered the long term effects of this approach (Nye 2002: 90-91).

In recent years, clarification on the foreign policy of Iran and breaking the Iranophobia atmosphere created in opposition to the measures of the USA and the West in the region and the world against Iran have been highly considered as one of the most vital and strategic issues in the foreign policy of Iran. For this reason, the Islamic Republic of Iran attempted to establish strategic relations at individual, institutional, and active social networks levels with the purpose of clarification and declaration of its positions. In the first level, the relation with key actors affecting the public opinion was considered. In the second level - the strategic relation with the non-governmental groups and institutions, non-governmental organizations, research centres, parties, and local media. In the third level - the relation with virtual networks, Internet networks, and social networks. The politicians of the Islamic Republic of Iran attempted to inform the audience and elites in the target societies with the details of this "constructive interaction" doctrine based on justice, realistic peacemaking and win-win interaction with the other parties.

The Islamic Republic of Iranian Broadcasting (IRIB) has always played a significant role in this regard with other domestic and virtual media. Although the role of the media is different, the Islamic Republic of Iran has always attempted to use modern media tools such as social, virtual, and new communication technologies in its new public diplomacy and soft power. Developing the information exchange and communication in the current epistemic and knowledge-based society creates a new culture of soft power which is based on clarity and explanation of opinions in the public area attempting to fulfill creativity, persuasion, illustration and flexibility. Presenting a positive image of the Islamic revolution values and regime, especially religious democracy, moderate foreign policy and multi-centered international system for the audience, is considered as one of the pillars of Iran's public diplomacy. Since the Islamic Republic of Iran is based on religious and Islamic teachings, big efforts were made for presenting an optimal image of the regime abroad and introducing a pure Islam based on balanced rationality in the new media environment. 
The development of long term relations with key actors

The relations with key actors, international media, political media, influencing groups, representatives of parliaments and research centers, influencing owners of business and economic positions, financial institutions and banks, owners of industries and big cartels can be the significant key to success of public diplomacy and soft power in transferring the message to the audience. Establishing the intercultural relations led and will lead to reliable results.

Another effective method in establishing sustainable relations with key individuals is the exchange diplomacy through which the authorities develop public-to-public relations (citizen diplomacy) as well as the cultural and academic exchanges and the sustainable relations with cultural and academic elites (track-two diplomacy). Reinforcing the Farsi language positions of universities, organizing Farsi language classes, sending the students, teachers, and those interested in studying the Farsi language to Iran are among the significant ways of culture-to-culture exchange, i.e. intercultural exchange (Dehsheiri 2014). Thus, the soft power of Iran relies on the measures such as sending students abroad, accepting academic scholarships in the sphere of educational diplomacy and internationalizing the system of higher education in the country, intercultural relations, art festivals, cultural seminars, and even creating Internet websites in the field of soft power to highlight developments in Iran with the balanced rationality of constructive interaction doctrine.

In fact, the most important target group of soft power is foreign elite, for it turns out to be a promoter of the goals of the relevant country if it is influenced. Thus, the soft power of Iran attempts to engage cultural audience with scientific, academic, cultural and artistic exchanges. In addition, cultural and educational exchanges and accepting the elites of other countries have been always considered as the profitable investments of foreign policy. Intercultural events to associate the culture of countries to each other have a significant effect on the institutionalization of cultural relations which is an effective propaganda for the Islamic Republic of Iran. Furthermore, the investment of government in tourism is considered by the policy making of public diplomacy and soft power of Iran to change the mentality of tourists about the Islamic Republic of Iran. As a result, the mass presence of tourists in Iran to see the facts of the Iranian society was observed.

\section{The evaluation of Iran's soft power}

As it was mentioned above, the soft power of the Islamic Republic of Iran includes structural and administrative factors which should work together to be effective. Iran possesses a number of instruments involving soft power and public diplomacy tools. Iran tries to make them interactive and coherent, but sometimes it is impossible. This is the key problem in Iranian public diplomacy. Sometimes employing them ended just in waste of capital.

The second challenge is that Iranian public diplomacy has not paid enough atten- 
tion to the professional media as well as non-governmental actors. The media plays a central role in informing the public about what happens in the world, particularly in those areas in which audiences do not possess direct access (Happer, Philo 2013:321). Non-governmental actors proved to be influential, especially in the western community, and these actors sometimes play even more effective role than the mass media. Iranian authorities should have full capacity to use these actors in line with public diplomacy as an effective soft power tool.

Therefore, in order to reach unity in the field of functional coordination of decision centers in the issue of soft power and public diplomacy, first of all the authorities should build a strong, powerful, and endowed structure of all current centers and reorganize all the centers and the actors, precisely define their structure, functions and activities, so that these components can provide effective feedback for the soft power and public diplomacy by doing centralized and coordinated activities with other actors. One of the key points in the issue of Iranophobia is the psychological war on Iran's nuclear threats. Signing and adopting the Joint Comprehensive Plan of Action (JCPOA) known commonly as the Iran nuclear deal, has disarmed the enemies of Iran. Tehran should also capitalize on the momentum of the Iran nuclear deal as a trust building measure, forge a network of states friendly to its interests and provide them with the necessary incentives to remain invested in such friendship through strategic partnerships, common projects and financial cooperation.

\section{Conclusion}

The main objective of the present study was to answer the question: "What is the place of soft power in the foreign policy of the Islamic Republic of Iran in confronting Iranophobia?". For this reason, the theoretical and conceptual framework of soft power was used based on the theory of Joseph Nye. Furthermore, the study explained that the tools of public diplomacy and soft power in Iran, rests on three main pillars: history and culture, political values and foreign policy which is the largest source of soft power. The authors also showed that the objective examples of soft power and public diplomacy in Iran are the Islamic Culture and Relations Organization and Iran's international media operations attempting to extend its soft power reach.

The Iran's public diplomacy and soft power, confronting Iranophobia and showing the reality of the Iranian society, is one of the main objectives of the government. To achieve this goal, it has used the tools and the objective example of public diplomacy and soft power. Thus, the adoption of "the doctrine of constructive interaction", balanced policy and rationality shown by the government could reduce the Iranophobia atmosphere internationally and regionally using the different tools of soft power such as media, virtual networks, articles, negotiations, official and unofficial visits and multiple debates with the other parties, cultural, academic and exchanges. Thus, the foreign policy of Iran has used this good opportunity and the tools of soft power such as public diplomacy to increase the influence of Iran in the region and global relations at 
a less cost than spending military costs or traditional diplomatic methods. The foreign policy of Iran could use the new concepts of national power to promote the status of Iran in global and regional exchanges, break the Iranophobia atmosphere displaying a destroyed face of the Islamic Republic of Iran to the world, and show the peacemaking nature of the Iranian society to the public opinion in the world.

Iran's public diplomacy and soft power can be considered the new forms of power, which include cultural, ideological, political and intellectual components. Values such as religious democracy and humanitarian assistances to liberation movements, promotion of scientific and cultural capabilities can be considered as soft power. It should be noted that soft power based on ideas of the Islamic Revolution has been something more than encouraging or inciting nations, for it includes the concept of ability to attract people that generally leads to consent and satisfaction.

The government of the Islamic Republic of Iran in the international relations and foreign policy areas focused on the realistic idealism and balanced rationality and created a balance between its goals and principles to put the public dimension of such relations on its agenda and pay special attention to the relations with the public opinion of other countries along with the formal relations with other governments. This was aimed at building a desired discourse, explaining the goals and achievements, coping with the media advertisements, removing the accusations against Iran, presenting a correct image of Iran in the world, and promoting the national interests. The smart use of three components of soft power and social networks had an effect on the audience. For example, after the Joint Comprehensive Plan of Action was signed, the global attitude to Iran was significantly smoothed and the Iranophobia atmosphere was broken.

Another effective method that was mentioned in this study was establishing a sustainable relations with key actors and exchange diplomacy by which the authorities develop citizen diplomacy and track-two diplomacy. This helps to exert influence on decision-makers of foreign policy and affect the output through intercultural influence. The Islamic Republic of Iran has always attempted to use this tool of applying power to achieve its goals which is coping with Iranophobia and establish a direct relationship between soft power and foreign policy because, according to many scholars, «the only way to defend the beliefs and principles of a country is to introduce them» (Eltiaminia, Taqvayi 2016). Thus, the policy-makers, decision-makers, and authorities in Iran are convinced that they have a real chance of success for Iran which can change the public opinion of the world and accelerate the movement in line with the determined goals.

It is also important to bear in mind that in order to cope with Iranophobia the Islamic Republic of Iran has to employ an balanced and realistic strategy, build a strong, powerful, and endowed structure of all existing institutions, define their structure, functions and activities. In this way these components will be able to provide effective feedback for the soft power and public diplomacy by doing centralized and coordinated activities with other actors and help the government to reach its goals. 


\section{About the authors:}

Seyyed Mehdi Mirmohammad Sadeghi - PhD Student in International Relations, North Tehran Branch, Islamic Azad University, Tehran, Iran. E-mail: smsadeghi@hotmail.com.

Rahmat Hajimineh - Assistant Professor of International Relations, Department of Communication and Social Science, East Tehran Branch, Islamic Azad University, Tehran, Iran. Email: r.hajimineh@gmail.com.

\section{Conflict of interests:}

The author declares absence of conflict of interests.

\section{Роль «мягкой силы» Ирана в борьбе против иранофобии}

Сейед Махди Мир Мохаммад Садеги, Рахмат Хаджи Мине DOI 10.24833/2071-8160-2019-4-67-216-238

Открытый исламский университет, Тегеран, Иран

«Мягкая сила» - комплекс действий, проводимых государством, региональным или международным актором с целью оказания влияния на общественное мнение за рубежом для улучшения своего имиджа и/или привлечения зарубежной поддержки в целях продвижения собственных интересов с использованием всех имеющихся инструментов и современных технологий. Статья посвящена анализу мер, проводимых правительством Ирана, в целях противодействия иранофобии - явлению, подразумевающему отрицательное восприятие Ирана, выражающееся во враждебном отношении к его политике, культуре, обществу, экономике и его роли в международных отношениях. Используя такие инструменты, как студенческие и культурные обмены, открытие центров изучения персидского языка (фарси), кино, туризм, а также деятельность специализированной организации, такой как Организация по исламской культуре и связям, Иран наращивает потенциал своей «мягкой силы» и публичной дипломатии. Данный вид дипломатии имеет особое значение для страны, поскольку его использование во внешнеполитической стратегии способствует укреплению национальных интересов и усиливает влияние на региональном и глобальном уровнях. Цель исследования заключается в том, чтобы, сформировав определение публичной дипломатии и «мягкой силы» в международной системе, дать оценку их применению во внешней политике Ирана с акцентом на изучение противодействия иранофобии. Авторы статьи также оценивают эффективность «мягкой силы» во внешней политике Ирана в деле противодействия иранофобии. В ходе исследования были использованы описательно-аналитический метод с акцентом на исторические свидетельства, архивные документы и существующие теории. В частности, анализ основан на синтезе теории «баланса угроз» Стивена Уолта и теории социального конструктивизма Александра Вендта для объяснения иранской «угрозы» во внешней политике США. 
Авторы статьи подчёркивают роль средств массовой информации и очерчивают теоретические и практические рамки «мягкой силы». Выводы, сделанные авторами в рамках настоящего исследования, свидетельствуют о том, что публичная дипломатия и «мягкая сила» Ирана позволила в определённой мере смягчить господствующую атмосферу иранофобии на региональном и международном уровнях, а также снизить влияние антииранской консолидации.

Ключевые слова: публичная дипломатия, Исламская Республика Иран, внешняя политика, иранофобия, «мягкая сила»

\section{O6 aвmopax:}

Сейед Махди Мир Мохаммад Садеги - аспирант, кафедра международных связей, отделение Северного Тегерана, Открытый исламский университет, Тегеран, Иран.

E-mail: smsadeghi@hotmail.com.

Рахмат Хаджи Мине - доцент, кафедра международных связей, отделение Восточного Тегерана, Открытый исламский университет, Тегеран, Иран. Email: r.hajimineh@gmail.com.

\section{Конфликт интересов:}

Авторы заявляют об отсутствии конфликта интересов.

\section{References:}

Asghari Rad J. 2011. An Introduction to Public Diplomacy. Tehran: Kosar Educational Research Center. 159 p. (in Farsi)

Dehsheiri M. 2014. Cultural Diplomacy of Islamic Republic of Iran. Tehran, Cultural and Scientific Publishing. 590 p. (in Farsi)

Eltiaminia R., Taqvayi Nia A. 2016. Explaining the Role and Place of Soft Power in Realizing the Goals of Domestic Politics. - Quarterly Journal of Political Research in Islamic World. No. 3. P. 167-196. URL: http://priw.ir/browse.php?a_code=A-10-503-1\&sid=1\&slc_lang=fa (in Farsi)

Ersig H., Toyserkani M. 2009. The Comparing the Power of Iran and USA in the Middle East. - Quarterly Journal of Political Science. Vol. 5. No. 2. P. 169-203. URL: http://ensani.ir/fa/ article/260696/ (in Farsi)

Gurgu E. 2016. The Role of Public Diplomacy in International Relations in Full Process of Globalization. - Annals of Spiru Haret University, Economic Series. Vol. 7. No. 2. P. 125-141.

Guha S. 2019. Sanctions Are Coming: Fear and Iranophobia in American Foreign Policy. E-International Relations, January. URL: https://www.e-ir.info/2019/01/07/sanctions-are-comingfear-and-iranophobia-in-american-foreign-policy/

Happer C., Philo G. 2013. The Role of the Media in the Construction of Public Belief and Social Change. - Journal of Social and Political Psychology. Vol. 1. No. 1. P. 321-336.

Leonard M., Stead C., Smewing C. 2002. Public Diplomacy. London: Foreign Policy Centre. $183 \mathrm{p}$.

Malek Mohammadi H., Davoodi M. 2012. The Effect of Iranophobia on Military Security Policies of the Persian Gulf Cooperation Council. - Politics Quarterly: Journal of Faculty of Law and Political Science. Vol. 42. No. 2. P. 227-246.

Melissen J. 2005. The New Public Diplomacy: Between Theory and Practice. In Melissen J. (ed.) The New Public Diplomacy Studies in Diplomacy and International Relations. London: Palgrave Macmillan. P. 3-27.

Melissen J. 2011. Beyond the New Public Diplomacy. Netherlands Institute of International Relations. Clingendael Paper No. 3. 34 p. URL: https:/www.clingendael.org/sites/default/files/ pdfs/20111014_cdsp_paper_jmelissen.pdf 
Mir Hosseini Z. 2001. Iranian Cinema. - Middle East Report. No. 219. URL: https://merip. org/2001/06/iranian-cinema/

Nargesi A. 2014. The Thought of Iranophobia and its Reproduction in USA Foreign Policy during Obama Government. Master's Thesis. Islamic Azad University. 121 p. (in Farsi)

Nye J.S. 2002. The Paradox of American Power: Why the World's Only Superpower Can't Go It Alone. New York: Oxford University Press. 240 p.

Ram H. 2009. Iranophobia: The Logic of an Israeli Obsession. Redwood City: Stanford University Press. 224 p.

Snow N., Philip Taylor M. (eds). 2009. Routledge Handbook of Public Diplomacy. London: Routledge, 2009. 404 p.

Speier H. 1950. Historical Development of Public Opinion. - American Journal of Sociology. Vol. 55. No. 4. P. 376-388.

Tamdemir E.O. 2017. Islamic Republic of Iran Diplomacy and Soft Power. Master Thesis. Ankara, Yidirim Beyazit University. 118 p.

Tsygankov A.P. 2016. Russia's Foreign Policy: Change and Continuity in National Identity. Lanham: Rowman \& Littlefield Publishers. 336 p.

Walt S. 1985. Alliance Formation and the Balance of World Power. - International Security. Vol. 9. No. 4. P. 3-43.

Wastnidge E. 2015. The Modalities of Iranian Soft Power: from Cultural Diplomacy to Soft War. - Politics. Vol. 35. No. 3-4. P. 364-377.

Wendt A. 1992. Anarchy Is What States Make of It: The Social Construction of Power Politics. - International Organization. Vol. 46. No. 2. P. 391-425.

Wilson E.J. 2008. Public Diplomacy in a Changing World. - The Annals of the American Academy of Political and Social Science. Vol. 616. P. 110-124.

Zaharna R.S. 2009. Public Diplomacy through the Looking Glass: Obama, US Public Diplomacy and the Islamic World. Symposium on Old and New Media, and the Changing Faces of Islam, sponsored by Religion, Media and International Studies Project. Syracuse University. 10 p. URL: https://www.american.edu/soc/faculty/upload/public-diplomacy-through-the-lookingglass.pdf

Zaharna R.S. 2007. The Soft Power Differential: Network Communication and Mass Communication in Public Diplomacy. - The Hague Journal of Diplomacy. Vol. 2. No. 3. P. 213-228.

Zarif M.J. 2014. What Iran Really Wants: Iranian Foreign Policy in the Rouhani Era. - Foreign Affairs. Vol. 93. No. 3. P. 49-59. 